\title{
Migrant land rights reception and 'clearing to claim' in Sub-Saharan Africa: A deforestation example from southern Zambia
}

\author{
Jon D. Unruh, Lisa Cligget, Rod Hay
}

\begin{abstract}
The relationship between migration and deforestation in the developing world continues to receive significant attention. However beyond direct population increase, the precise mechanisms that operate within the intersection of migrant - host land rights remain largely unexamined. Where migrants are provided with land and rights by the state and/or local communities, how such rights are perceived by the migrants is of primary importance in their interaction with land resources, and in aggregate it impacts the development opportunities and environmental repercussions of migration. The authors analyze the operative aspects of land rights reception (as opposed to provision) by migrant populations, and the relationship between this reception and deforestation. The article examines a case in Zambia to analyze how tenurial constructs, emerging from the way rights are perceived by migrants, lead to the continued clearing of areas much larger than needed for cultivation, even when the arrangement appears counter-productive in terms of land rights provision and labour allocation. While valuable policy efforts have focused on providing resource rights to migrants, how such rights are received and the relationship of this reception to resource management needs greater policy attention.
\end{abstract}

Keywords: Land tenure; Deforestation; Zambia; Migration; Africa; Agriculture.

\section{Introduction}

Increasingly, pervasive rural migration in the developing world is emerging as a significant trend in environmental change scenarios and alterations in the resource use systems that are important to development. The impact on natural resource of migrants is directly linked to issues of land access and use, which interacts with local communities who have pre-existing claim and use rights. In this context, land tenure plays a primary role in determining how migrants interact with resources and communities in their new location, and the resulting environmental consequences and development possibilities.

In most areas receiving inflows of migrants, local (non-migrant) communities play an important role in granting land access to the newcomers, even when the State is involved. The tenurial constructs that emerge to in relation to migrants' land rights plays a fundamental role in directing trajectories of land use either toward conservation of natural resources and sustainable development, or towards land degradation and subsequent out-migration. While provision of rights to migrants by State or local authorities can be seen as adequate enough to provide for secure, conservative resource use by migrants, how migrants themselves actually perceive and use such rights has important repercussions on the way migrants use their new land, and therefore ultimately for environmental change. 
Jon Unruh is at the Department of Geography, McGill University, Montreal, Quebec, Canada

$<$ jon.unruh@mcgill.ca>

Lisa Cligget is at the Department of Anthropology, University of Kentucky, Lexington, KY.

Rod Hay is at the Department of Earth Sciences, California State University

Dominguez Hills, Carson, CA

The relationship of this reception to the perceived adequacy of evidence for rights received, and the resulting deforestation by migrants in an attempt to gain additional evidence, in a 'clearing to protect rights' approach, has not yet been attended to in the literature. This article examines how migrants' insecurity about tenure in their new locations plays a role in deforestation, which is related to the adequacy of evidence (both provided by host authorities and derived by migrants) to establish their rights to the claim. Important considerations include: the difference between learning about rights provided, and believing in evidence attesting to those rights; the role of 'others' in a combined migrant - non-migrant community in a context of dispute; and the critical role of experience in relation to evidence of rights received.

After a discussion of the intersection between migration, environmental change and land tenure -- which has been left out in current literature on migration and deforestation -- the article focuses on the problem of migrants' perception of rights. The article then looks at a case of deforestation in southern Zambia, where this condition has been precipitated by migrants' attempts to secure evidence of land rights to their new location. The article concludes with a discussion of the kinds of research and policy attention required to penetrate problems related to migrant land rights among small-scale resource users.

\section{Migration, environmental change, and land tenure}

The migration literature has much to offer towards a fundamental understanding as to why migration occurs, and choices and decision-making available to migrants as to destination areas (e.g., Lucas and Stark, 1985; Massey, 1993; 1990; Massey, 1998; McGregor, 1994; Townshend, 1997; Schmeidl, 1998). But while migration is recognized as a primary driver of resource degradation, and significantly complicates efforts towards conservation and sustainable development, the literature has only recently begun to address the aggregate role migrants play in large-scale environmental change. Studies on environmental outcomes of migration have examined deforestation, agriculture, the character of migrants, and the dynamics of destination areas (e.g., Amacher et al., 1998; Myers, 1997; Doos, 1994; Ghimire, 1994; IUCN, 2000; Stone, 1997). Much of this valuable work operates from the notion that environmental change is a straightforward result of local population increases due to in-migration. But the body of literature lacks an examination of the precise mechanisms embedded within processes by which the arrival of migrants causes such change in their new location, and the relationship of this process to possibilities for conservation and sustainable development.

Recent studies have contributed significantly to our understanding of the important role of land tenure in the way people interact with their environment (Katon et al., 2001; Ostrom et al., 2000; 
Amacher et al., 1998; Thesihuesen, 1991; Southgate, 1990) and the way land tenure, in aggregate, plays a primary role in land cover change at various scales (Unruh, 1995a). While the literature recognizes that land tenure influences the way migrants interact with their new community and its resources (Katon et al., 2001; Ostrom et al., 2000; Amacher et al., 1998; Thesihuesen, 1991; Southgate, 1990; Unruh, 1995a), it neglects the influence of migrant land tenure itself (tenurial constructs held by the migrants themselves) on environmental change. This is of particular concern, given the general recognition that conservation and sustainable development require significant cohesion on the part of the community in participation, enforcement, and derivation of benefits. Such cohesion may be problematic between newly arrived migrants and their local hosts, as migrant and local populations hold different positions with regard to access and claim to land, and use of land resources. In this context, the major land tenure issues that emerge in parallel with increased rural migration are associated with a significant increase in legal pluralism in land tenure -- or multiple operative notions about resource use, access, claim, and security if tenure. While tenurial legal pluralism alone does not necessarily lead to resource degradation, the combination of migration and legal pluralism in a context of resource use by smallholder farmers creates situations that can lack mitigating institutions and rules to prevent environmental degradation. Studies on legal pluralism in the developing world address migrant land tenure issues, but to date have focused more on the intersection of the various legal domains, and not on the effects of pluralism on resources necessary for food security, conservation, and sustainable development (von Benda-Beckmann, 1995; Galanter, 1981; Lund, 1998; Prill-Brett, 1994; Vel, 1992).

Studies of frontier regions in Brazil (Brondizio et al., 1994; Moran et al., 1994; Walker et al., 2000), Mexico (Haenn, 1999, in press) and West Africa (Stone, 1997, Nyerges et al., 2000) echo our assertion that the migrant phenomenon in new land settlements includes important local level dynamics of resource access, security, and socio-political control, and requires better understanding. Recent work in Mozambique (Unruh, 1998; 2001; 2002b), and Somalia (Unruh, 1993 ; 1995b; 1996) focuses on the important role that evidence, migration, and perception of rights plays in customary land tenure systems, and how this facilitates or complicates access and use of resources for local communities, migrants, commercial activities, and national and international interests in conservation. Work by Amacher et al., (1988) in the Philippines and more broadly by Myers (1997) articulates the relationship between migrants' choice of destination, tenure insecurity in destination areas as a pull factor, and deforestation as migrants then attempt to secure their tenure upon arrival. While these works have contributed much to current knowledge about different aspects of the tenure-deforestation nexus, insight is lacking into the ways that migrants' understanding of land rights allocated to them interact with their own needs with regard to land tenure, and subsequently impacts on resource management and sustainable agriculture. 


\section{Migrants' reception of land rights: evidence and community}

\subsection{Evidence of claim and security of tenure}

Bruce and Migot-Adholla (1994) state that legitimate evidence of land holding should provide sufficient security of tenure. However, this theory fails to explain cases where legitimate evidence of rights is granted to migrants by local and/or State authorities, and where migrants nevertheless persistently clear land beyond what is needed for near-term cultivation in order to gain additional evidence for their claim to the area. Security of tenure resides to a significant degree in the domain of perception, and thus what non-migrants may perceive to be clear evidence of assured security of tenure, may not be relevant to the migrants themselves in terms of what they perceive to be required for secure tenure (Unruh, 2002a; 1997a). Brazil's grand colonization schemes in the Amazon provide examples of similar cases, where in spite of the Government having provided migrants with land titles, migrants themselves, in some cases, clear much more land than they can cultivate, in an effort to secure their claim (Fernside, 1986; Postel, 1988). Other examples of clearing to land to secure claim can be found in the Philippines (Uitamo, 1999) and Uganda (Mulley and Unruh, 2004; Aluma, 1989)

In reality, migrants may have only limited understanding of the land rights system prevalent at their destination, so that they may have significant difficulty in translating local (community, or State) traditions and institutions relating to the provision of land rights and relevant evidence for such rights into their own experience and hence into meaningful practice. Local smallholders use an array of customary evidence to connect them to their community and to community land, where history of occupation and physical signs of current occupation play a significant role. Local customary institutions for the resolution of land disputes may accept as legitimate evidence of tenure, for example, membership in the local community and clans, and testimony from lineage and community members regarding the history of the land use and occupation in question. Migrants do not posses such evidence. Instead they hold rights recently granted to them, and evidence to those rights is apparently provided by local customary leaders or State authorities. But this evidence is largely untested with regard to the rest of the community of locals and recently arrived migrants. For migrants, more basic, fundamental and easily observed evidence - primarily, cleared land -- can better contribute to security of tenure than provision of evidence by authorities (customary or State) that can be less observable and more socially dependent.

\subsection{The migrant - non-migrant community}

To a significant degree, security of tenure for an individual is less about the rights he/she possesses than about the respect of a community (broadly defined) for those rights (Unruh, $2002 \mathrm{~b}$; 2003). Fundamentally, security of tenure is about the role played by the community. Where locals and migrants find themselves in one broad community, the degree to which an individual believes that others in the community are willing to respect his or her rights, based on specific evidence attesting to those rights, is fundamental to the individual's sense of security in 
their tenure (Unruh, 2003; 1997a). As newcomers, migrants may believe that they are second class members of their new community; in many cases this belief stems from their own experience. This perception may prevail over other indications of actual adequate provision of rights. The degree to which such a notion becomes an obstacle to believing that adequate rights have actually been provided, and will be respected by the community, significantly depends on the migrants' own experience with the host community during the time --often short -- that they have been there.

What counts for migrants -- even if sufficient rights have been provided and the migrant fully understands these rights -- is the experience of holding evidence showing that those rights successfully function (or not), in the way claims and rights are contested over time in disputes and other interactions involving migrants vs. locals (Unruh, 1997a). How such issues are resolved provides perhaps the most important experience for migrants regarding the nature of the rights they have been provided and the evidence they hold. If evidence used in resolving disputes is equally available and legitimate, then this will be an important experience for migrants that rights provided to them are indeed upheld and valid. But such an ideal case is unlikely. Even in situations where there is intent to treat migrants and locals equally in disputes, in reality the evidence that facilitates this is rarely equally available. Membership in a lineage, or ethnic group, length of time in residence on a parcel or in an area or as part of a community, history of interaction with other community members over land, testimony from other community members, knowledge of an area, history of connection to cemeteries, sacred areas, economic trees, field boundaries, and locations of old crops (Unruh, 2002a) all favour local community members over migrants, even when the authority and institutional aspects of the dispute are fair. The problem of course, is that migrants know all this before a dispute arises and seek to augment the evidence in their favour by clearing more land than they need for cultivation.

While a migrant may possess certain evidence in a dispute, this may differ depending on the migrant's specific interactions with the community and the landscape as compared to the position of locals, in addition to whatever evidence may be available regarding rights granted by an authority. In a study of the differences in evidence presented in disputes between local customary smallholders and migrants in Mozambique, Unruh (1997a; 2001) found that the evidence available to the two groups (migrant and local) differed significantly. Migrants relied primarily on physical evidence, while the evidence presented by non-migrants was more socially, culturally or ecologically based.

The primary focus of this article is the disconnect between land rights and evidence thereof as provided by local or State authorities on one hand, and the continued insecurity of tenure experienced by migrants, on the other, due mainly to the way migrants perceive such rights. The increased deforestation, resulting from migrants seeking to bolster the evidence of their rights of tenure, is a central issue in migrants' interaction with the resources at their new settlement location. It is argued here, that a greater understanding of how rights to land resources and evidence thereof are perceived by migrants, in terms of their own expectations, and the experience of migrants over time in their new settlement (reception), is critical to penetrating this 
phenomenon. The literature in this regard is spare. Where the literature on land tenure examines customary perceptions of rights, it does not include cases of migrants. Yet it is known that dislocation and migration profoundly change social relations, particularly with regard to land tenure, thus altering experience, and expectation of claim, use, and predictability, and hence security of tenure.

The relevant question, then, is whether a positive experience of the validity of tenure rights provided will render evidence, other than that of cleared land, increase in importance, and whether clearing of land in excess of what is needed for near-term cultivation will become less of a necessity? If this is the case, how will the rate at which such a reversal occurs compare with the rate of deforestation linked to clearing for claim?

\section{The case of Zambia}

\subsection{Clearing to claim}

Issues of migration and environmental change are acutely pertinent to sub-Saharan Africa where some of the highest rates of deforestation in the world exist alongside of some of the largest most pervasive and problematic migrations. The neighbouring states of Zambia, Democratic Republic of Congo, and Zimbabwe are among the top ten countries in the world for rates of deforestation, and among the top four in Africa (FAO, 2001). Zambia's Southern Province provides a particularly interesting and representative example of a chain of related migration events over a 24-year period, tied to environmental change in the context of deforestation and degradation of agricultural land. In the Zambian case, we find that local leaders provide migrants with rights to land that by all indications are as secure as, and much the same as, those enjoyed by non-migrant locals. Nevertheless, the land rights thus provided are received by migrants much differently than by locals, and from our fieldwork we find that this leads migrants to clear much larger areas than

are subsequently cultivated, for purposes of creating evidence of their claim to the land they have already been allocated. This practice requires substantial additional labour inputs, and leads to high rates of deforestation and ultimately unsustainable resource use. While the 'clearing to claim' hypothesis is examined here, others are, of course, possible.

\subsection{Background}

The case described here draws on recent fieldwork and writing on Zambia from 1992 to the present (Cligget, 1997; 2000; 2001a; 2001b; 2002; in press-a) and on fieldwork in southern Zambia during the years 2001 and 2004, as well as on data and literature emerging from the longitudinal Gwembe Tonga Research Project (GTRP), a social science study from 1956 to the present, in southern Zambia. The GTRP is one of the longest lasting studies of this type over a population in Africa (Van Kemper and Royce, 2002; Scudder and Colson, 2002; Cliggett, 2002). In 1958, approximately 57,000 members of the Gwembe Tonga tribe were forcibly relocated due to the construction of the world's largest artificial reservoir at the time - Lake Kariba in the Middle Zambezi Valley (Colson, 1960; 1971; Scudder, 1962; Scudder and Colson, 2002). The population was relocated to a series of villages along the lake and below the dam, where significant degradation of agricultural land took place over the next two decades in conjunction 
with land access problems (Cliggett, 2001a; 2000; Scudder and Habarad, 1991). From 1979 to the present, outmigration from the Gwembe Valley has occurred, primarily due to these degradation and access problems (Cliggett, 2001a; 2000; Scudder and Habarad, 1991). One of the main destinations has been a frontier plateau region -- the dense, dry Miombo woodland -near the Kafue National Park (Africa's largest park) within the Bilili Game Management Area in Zambia's Southern Province (Cliggett, 2000). While not the only settlement areas to which the Tonga are moving, it is the major one.

The dynamics of land rights and perceptions of those rights are well documented for the Gwembe Tonga in the valley region. In the Gwembe Valley, matrilineal clan groups oversee large land areas that are allocated to individuals and their families indefinitely, as long as the land is 'needed' by the people in question. Upon the death of a primary land user, the land reverts to clan holdings for subsequent redistribution. Although the Gwembe Tonga people share the same institutional systems for land allocation, use and inheritance, conflicts often arise over field borders, with accusations that one farmer has 'jumped' into another farmer's land (Colson, 1963; Colson, 1964; Colson, 1995). Conflicts such as these are resolved in headmen's courts, where a community of elders consult on the issue and make recommendations for penalties and payments. Outcomes are accepted by both parties, but conflicts nevertheless can, and often do, arise again in subsequent years (Colson, 1995).

The context on the plateau above the Gwembe Valley offers an opportunity to look at a migrant host situation, where the differences between the two are relatively small. In cases where greater differences exist between host and migrant populations, in terms of land-use, socio-cultural and ethnic aspects, it can be argued that the tenurial disconnect can also be great, with less coordination and more serious potential impact on the environment. However, on the plateau in southern Zambia, both populations are ethnically Tonga, speak the same language, share many social, kinship and religious institutions, and engage in very similar forms of agriculture, yet the environmental impact associated with host - migrant interaction nevertheless appears quite considerable in terms of deforestation.

Preliminary calculations in the study area indicate that total area of cleared agricultural land more than doubled between 1986 and 2000. For this estimate, Landsat thematic mapper satellite imagery was used to identify only agricultural areas during the dry season, in July. The agricultural area was assessed based on bare soil signatures during this period. Cultivated fields are shown to be dispersed, which reflects the manner in which land is allocated, as also confirmed by fieldwork: relatively large areas are allocated, containing comparatively small areas within them that are under active cultivation. Thus, areas within such allocations that were initially cleared (for claim) but not subsequently cultivated, and have since regrown into bush would not be visible. Future remote sensing work will attempt to identify and quantify this latter category of land, and ground-truthing of the satellite imagery will also be undertaken to insure that proper identification has been made. 
Significant confusion exists with regard to the actual status of the Bilili Game Management Area. While resident Tonga chiefs contend that the area has been degazetted - in effect devolving control of the area to traditional land administrative systems (Cliggett, 1997; 2000) there is disagreement among state officials as to the current status of the area and the actual process of degazetting. In reality, de facto administration and management of land access and control of the area resides with the local chiefs and their headmen, due to both their long presence in the area, and lack of enforcement by the State (Cligget, 2000).

\subsection{Land allocation to migrants}

Upon arrival in a new location, migrants acquire and clear land, but their approach to this process presents problems. Migrants acquire land by requesting an area from representatives of the local chief or headman. The local leadership usually grants such requests, in part because land is still abundant in the area, but to a large degree also because adding people increases the political base of a headman or chief. Such a population base is important to the chief's interaction with other chiefs and with the State, and as a result, chiefs are liable to allocate as much 'unused' land as feasible. Thus, to a significant degree, it is in the chief's interest to allocate real, secure and working land rights to migrants as well as evidence attesting to those rights. From our research, this also appears to have taken place. In fact, it is very rare for migrants to be relieved of land they are cultivating or have cleared, even they have incurred serious transgressions against the community. Part of the reason that local leadership allocates more land to migrant households than is needed for near-term cultivation, is the expectation that dependents will join the migrants in the future, which would contribute further to the chief's political base.

To establish land tenure, upon the approval of the headman, the headman himself the village committee (comprised of elders), neighbouring landholders, and the migrant in question locate and delineate a tract of land by walking around the perimeter and placing a specific mark on trees which then outline the boundary of the allocation. Once his or her lot has been allocated, the migrant begins clearing land for cultivation - this is done by girdling the trees (making a circular cut around the tree removing the bark) and then burning the trees once they are dead. However, this process plays out differently among migrants than among locals. During field work conducted in 2001 and 2004, the authors found migrants to clear much more land than they intend to cultivate. It was observed that migrants always cleared land (beginning along the boundaries of their allocation) and always farmed, but they never farmed an area as extensive as the one they had cleared. Migrants continued the clearing process until they had reached the limits of the land that they had been allocated, often of a significant size. This is a different system of clearing for agriculture than what is practiced by locals, who only clear the amount of land they intend to plant that season. In an environmental context, this is the defining physical distinction between migrant and local land tenure. 


\subsection{Two patterns of clearing to claim}

Our most recent research in southern Zambia reveals the existence of two broad patterns of land clearing by migrants for the purpose of establishing additional physical evidence of the landholdings they have been allotted by the local leadership. The first pattern involves migrants moving to a area where land is significantly abundant, and quickly clearing land provided by a local headman for fear that the local leadership itself may otherwise take back any land left apparently uncultivated. In this case, rights as well as evidence attesting to such rights provided by local leadership are seen by migrants to be tenuous; and migrants, as a result, may feel that additional evidence is urgently needed to solidify their claim in the face of what is perceived to be capricious leadership.

The second pattern exists in areas where land is no longer abundant, and where all land has already been allocated either to locals or migrants. Such areas may include both cultivated land and remnant forest patches within cultivated allotments. In this type of situation, new migrants arriving in the area looking for land may approach the local leadership and make the case that patches of apparently unused forest land should be taken from the current holder and allocated instead to the new migrants. Also, when youth in the area come of age and need land to start their own household and farming activities, there may be pressure to find land in the area. Such situations can render forested portions within land allocations vulnerable to allegations of nonuse, even if the landholder may in reality be holding such areas in reserve for future use by their children, for the gathering of minor forest products, for grazing, collection of fuel wood, or other household uses. This context thus encourages holders of forest patches to clear these so as not to incur allegations of non-use by others seeking land. In such cases, the need to clear is based on the perception that currently held evidence for holding forest land is not sufficient grounds for a migrant to guarantee continued rights of tenure.

One case, documented during field work in 2004, is an example of clearing practices - in this instance tied to time of acquisition (i.e., long-term resident versus recent arrival). The two farmers in question (named here Albert and Bradley -- not their real names) share one border between their agricultural fields. The senior man in the situation, Albert, while not a headman, has been resident on his plot of land since the early 1980s. Information on the actual size of the land holding was not available, but the farmer was described by others in the community as having 'a lot' of land. In fact, over the past decade, he had given portions of his land to a variety of relatives and newcomers to the area.

The younger man, Bradley, had requested, and received, a portion of land from Albert in 1996; this plot was at that time still forested. The basis of Bradley's request gained substance by the fact that his father shared a distant kinship link with Albert. This link constituted a social basis for the request beyond the simple appeal to generosity. Albert gave Bradley a portion of his land, a lot that was then still woodland. Upon receiving the land, Bradley immediately began clearing trees, and by the second year of his residence, he had rid his entire plot of its forest cover. From the time he first settled until the present, Bradley has been cultivating approximately half of the area -- the same half. When asked why he did not farm the whole area, he claimed lack of 
farming implements as the primary reason. Given that he was a relatively young man when he obtained the plot, early in his household life-cycle and with children all under five years of age, it is unlikely that he anticipated gaining the labour or the implements necessary for farming a large area. With this in mind, the authors asked why he had cleared all the land so quickly, knowing that he did not have the means to actually farm it. His exact answer was, "To protect the land so that it will not be given to someone else."

At the same time that Bradley's land has been cleared of all trees and shrubs, although the unfarmed portion is now in 'scrub' (regrowth) condition, the portion of Albert's land bordering Bradely's remains primary forest, having never been cleared. This case illustrates several points. The distinction between a the land of a long-term resident and that of a recent arrival can be seen in the landscape in terms of forest cover. Additionally, Bradley's candid statement that clearing forests would 'protect' his land from being reallocated indicates a lack of, at least perceived, security for a recently arrived resident. Thus, earlier arriving migrants who have not cleared all their land may face significant pressure from more recent arrivals -- especially those that may have a kinship link -- to give up some of their land, backed up by that fact that little other land still remains available in the area, and acknowledgement on the part of the headmen that land previously allocated still remains forested - thus 'unused.'

\subsection{The labour problem}

A related aspect of the migrant approach to land directly contradicts notions of small-scale sustainable, and efficient farming (Boserup, 1965; Netting, 1993). When migrant farmers return to areas cleared in the past, but not cultivated, they face dense bush and a significant mass of grassy roots, which requires a much greater labour investment to re-clear and prepare for planting than the initial effort of 'girdle and burn' clearing of the original tree cover. In effect, migrants clear significant portions of their land twice prior to cultivation, which takes a considerable investment of labour. Thus, even in areas of land abundance, farmers nevertheless appear to invest massive labour inputs similar to what would be applied under conditions of high population density and limited land availability. This practice highlights the link between insecurity of tenure and clearing for purposes of claim -- despite the significantly higher labour costs -- and ultimately underscores the environmental impact of migrant land settlement.

\subsection{Further research issues}

While the Zambian case is intended to be largely illustrative here, continued research by the authors will focus on issues intended to provide for improved articulation of migrants' perception of land tenure rights. The most pressing questions are, what is the precise difference between the tenurial position of migrants and that of locals, given that rights to land are given to migrants by local authorities. An important related question is, does this differentiation diminish or vary with time, with experience in matters relating to land, with evolving family relationships between migrants and locals, or with the presence or absence of institutional opportunities (customary or State) for the resolution of disputes. Distinctions between migrants and hosts will certainly diminish as the two groups increasingly engage with each other through mutual efforts in 
community building, such as the establishment of schools and clinics, work to encourage tourism and install local infrastructure, as well as through intermarriage and subsequent generational linkages. The question then becomes, in what ways do land rights change over time as the social separation between migrants and hosts decreases, and does a parallel change take place in the perception of legitimacy of access on the part of the population? If the difference between migrant vs. local tenurial rights diminishes over time or with experience, then presumably security of tenure for migrants would correspondingly increase, and consequently the need for certain forms of securing claim (such as clearing land) would also diminish in importance. The rate at which this happens would in turn be relevant to the rate of deforestation resulting from migrants clearing for purposes of bolstering the evidence of their tenure rights. The rate of acquisition of experience, however, would be difficult to measure for all migrants, because while pioneer migrants would have significant inexperience within local communities, this would not apply to migrants who are relatives and neighbours and who join them later.

Important questions remain, and the intention of the authors here is to share a set of questions that may be of interest to other researchers working on issues relating to land tenure, migration, decentralization, sustainable development, environmental change, and conservation in the developing world. In particular, the authors believe the following topics need to be investigated.

- Does the distinction between the type of evidence accepted as proof of land tenure rights for migrants and for locals (e.g., membership in a local lineage or ethnic group, testimony from other lineage members, etc., as well as type and strength of evidence) decrease over time? If, indeed, it does, what are the mechanisms triggering such change? Is it speeded by the presence of local courts, or by state or customary institutions of equal utility to both migrants and locals? In what ways does social interaction, such as intermarriage and child rearing, influence perceptions of evidence and security of land tenure?

- Does the importance to migrants of clearing land as a way to augment evidence of their land tenure rights, and as a reaction to exclusion from other important forms of evidence open to locals (lineage, duration of residency, etc.), decrease with an accumulation of other viable forms of evidence, or an increase in its credibility, or the presence of local or State authorities that could make legally binding allocations?

- If there are linkages between a decrease over time in the difference between the justification for migrants' and locals' claims to land tenure, an increase in security of tenure, and a decrease in the area that migrants need to clear for purposes of solidifying their claim, then how powerful and pervasive are these linkages? Are they easily overwhelmed by other social, political, and environmental forces in the larger migrant local society? 


\section{Policy considerations}

Information about how migrants view their newly acquired land rights can inform current approaches regarding the interaction between security of tenure and resource conservation in migrant destination areas. More generally, negative conservation outcomes associated with smallholder land management is often connected to the notion that 'enough rights' have not been provided to smallholders (e.g., Olowu, 2003; Romeo, 2003; Francis and James, 2003; Nielson, 2002), and thus the provision of rights to those engaged in small-scale resource use are not sufficient to allow for 'ownership' of management decisions and their consequences (Johnson and Forsyth, 2002; Kull, 2002; Agrawal and Ostrom, 2001; Kohl, 2003; Ribot, 2003; Latham, 2002). But if the problem is the migrant's lack of faith in the veracity of rights provided (and in the utility of existing justifications for the granting of these rights), then the provision of more rights will do little to encourage conservation. Non-migrant communities may have a certain experience (gained over the long term) that has allowed them to come to the conclusion that specific justifications with regard to land entitlement in fact provide for adequate security. This has to do with how evidence has operated with regard to disputes over land, and how past experiences with investment in land, inheritance, lending, etc. (all of which produce additional justification), have resulted in continued secure tenure. Migrants have no such experience in their new location within a community comprised of non-migrants and other migrants. Is gaining such experience over time more important to security of tenure than an ill-defined notion of what are 'enough' rights? Are there avenues other than time to providing valuable evidence to migrants? For example, in the Zambian case, if the headmen's land allocations to migrants were made binding by the State, would this be additional justification for continued land grant that would reduce the need for clearing land?

As migration trends continue to become more pervasive, development efforts concerned with the agriculture - environment nexus will increasingly need to engage the operative aspects of how migrants and locals interact in relation to rights of tenure. While provision of resource rights to smallholders has been well considered, how rights are perceived by migrants and the consequent environmental repercussions, have not. Given the severity of current trends in environmental change and viable agriculture, the 'rights perception problem' constitutes a significant gap in both academic and development knowledge.

\section{Acknowledgement}

Funding for this research was provided by the National Science Foundation, award number: 0236933.

\section{References}

Agrawal, A., Ostrom, E., 2001. Collective action, property rights, and decentralization in resource use in India and Nepal. Politics and Society, 29: 485-514. 
Aluma, J., 1989. Settlement in forest reserves, game reserves, and national parks in Uganda. Land Tenure Center, University of Wisconsin, Madison, WI, USA.

Amacher, G.S., Cruz, W., Gerbner, D., Hyde, W.F., 1998. Environmental motivations for migration: population pressure, poverty and deforestation in the Philippines. Land Economics, 74: 92-101.

Benda-Beckmann, F. von., 1995. Anthropological approaches to property law and economics. European Journal of Law and Economics, 2: 309-336.

Boserup, E., 1965. The Conditions of Agricultural Growth. Aldine Publishing, Chicago, USA.

Brondizio, E., Moran, E., Mausel, P., Wu, Y., 1994. Land use change in the Amazon Estuary: patterns of Caboclo settlement and landscape management. Human Ecology, 22: 249-279.

Bruce, J.W., Migot-Adholla S.E., 1994. Searching for Tenure Security in Africa. Kendall/Hunt Publishing Co, Dubuque, USA.

Cliggett, L., in press-a. Male wealth and claims to motherhood: Gendered resource access and intergenerational relations in the Gwembe Valley, Zambia. In: Clark, G. (Ed.), Gender in Economic Life: Annual Readings in Economic Anthropology. Academic Press of America, New York, NY.

Cliggett, L., 1997. Economic and Social Components of migration in two regions of Southern Province, Zambia. CDS Report /97. Center for Development Studies, University of Bath, UK..

Cliggett, L., 2000. Social components of migration: Experiences from Southern Province, Zambia. Human Organization, 59: 125-135.

Cliggett, L., 2001a. Carrying capacity's new guise: Folk models in anthropology and the longitudinal study of environmental change. Africa Today, 48: 3-20.

Cliggett, L., 2001b. Gender, subsistence, and residential arrangements for the elderly in the Gwembe Valley, Zambia. Journal of Cross Cultural Gerontology, 16.

Cliggett, L. 2002. Multi-generations and multi-disciplines: Inheriting fifty years of Gwembe Tonga research. In: Van Kemper, R., Royce, A. (Eds.), Chronicling Cultures: Long-Term Field Research in Anthropology. Alta Mira Press, Walnut Creek, CA.

Colson, E., 1960. Social Organization of the Gwembe Tonga. Manchester University Press, Manchester, UK 
Denevan, W., 1982. Causes of deforestation and forest and woodland degradation in tropical Latin America. Report to the Office of Technology Assessment, Congress of the United States, July 16, 1982. Assessment of Technologies to Sustain Tropical Forest and Woodland Resources, Washington, D.C. pp. 25-43.

Doos, B.R., 1994. Environmental degradation, global food production, and risk for large-scale migrations. Ambio, 23: 124-130.

Fernside, P.M., 1986. Spatial concentration of deforestation $\mathrm{n}$ the Brazilian Amazon. Ambio, 15: 74-81.

Francis P, James R., 2003. Balancing rural poverty reduction and citizen participation: the contradictions of Uganda's decentralization program. World Development, 32: 325-337.

Food and Agriculture Organization of the United Nations (FAO), 2001. Tropical countries continue to lose forests at high rate: Zambia. State of the World's Forests, FAO, Rome.

Galanter, M., 1981. Justice in many rooms: courts, private ordering and indigenous law. Journal of Legal Pluralism, 19: 1-47.

Ghimire, K., 1994. Refugees and deforestation. International Migration, 32: 561-569.

Haenn, N., in press. Nature regimes in southern Mexico: A history of power and environment. Ethnology.

Haenn, N., 1999. Community formation in frontier Mexico: accepting and rejecting new migrants. Human Organization, 58: 36-43.

IUCN, 2000. IUCN-CEESP Environment and Security Task Force Briefing. Presented at the World conservation Conference, Amman.

Johnson, C., Forsyth T., 2002. In the eyes of the state: negotiating a 'rights-based' approach to forest conservation in Thailand. World Development, 30: 1591-1605.

Katon, B., Knox, A., Meinzen-Dick, R., 2001. Collective action, property rights, and devolution of natural resource management. Policy Brief Number 2, CGIAR Systemwide program on Collective Action and Property Rights, International Food Policy Research Institute.

Kohl, B., 2003. Nongovernmental organizations as intermediaries for decentralization in Bolivia. Environment and Planning C-Government and Policy, 21: 317-331.

Kull, C.A., 2002. Empowering pyromaniacs in Madagascar: ideology and legitimacy in community-based natural resources management. Development and Change, 33: 57-78. 
Latham, C.K., 2002. Manyame catchment council: a review of the reform of the water sector in Zimbabwe. Physics and Chemistry of the Earth, 27: 907-917.

Lemel, H., 1988. Land titling: conceptual, empirical and policy issues. Land Use Policy, 5: 273-290.

Lucas, R., Stark, O., 1985. Motivations to Remit: Evidence from Botswana. Journal of Political Economy, 93: 901-918.

Lund, C., 1998. Struggles for land and political power: on the politicization of land tenure and disputes in Niger. Journal of Legal Pluralism, 40: 1-22.

Massey, D., 1990. The Social and Economic Origins of Immigration. Annals of the American Academy of Political and Social Science, 510: 60-72.

Massey, D., 1993. Contemporary theories of international migration. Population and Development Review, 19: 431-466.

Massey, D., 1998. Worlds in motion: understanding international migration at the end of the millennium. Oxford University Press, Oxford, UK.

McGregor, J., 1994. Climate change and involuntary migration: implications for food security. Food Policy, 19: 120-132.

Moore, H., Vaughan M., 1994. Cutting Down Trees: Gender, Nutrition, and Agricultural Change in the Northern Province of Zambia 1890-1990. Heinemann, Portsmouth, USA

Moran, E., Brondizio, E., Mausel, P., Wu, Y., 1994. Integrating Amazonian vegetation, land-use and satellite data. BioScience, 44: 329-339.

Mulley, B.G., Unruh, J.D., 2004. The role of off-farm employment in tropical forest conservation: labour, migration, and smallholder attitudes toward land in western Uganda. Journal of Environmental Management, 71: 193-205.

Myers, N., 1997. Environmental refugees. Population and Environment, 19: 167-182.

Nielsen, H.A., 2002. The role of donors: how to combine sector programs support with devolution? A comment from a practitioner to James Wunsch: 'Decentralization, local governance and 'recentralization' in Africa'. Public Administration and Development, 22: 175-178.

Netting, R., 1993. Smallholders, Householders: Farm Families and the Ecology of Intensive, Sustainable Agriculture. Stanford University Press, Stanford, CA. 
Olowu, D., 2003. Local institutional and political structures and processes: recent experiences in Africa. Public Administration and Development, 23: 41-52.

Ostrom, E., Burger, J., Fields, C., Norgaard, R.B., Policansky, D., 2000. Revisiting the commons: local lessons, global challenges. Science, 284: 278-282.

Postel, S., 1988. Global view of a tropical disaster. American Forests, 94: 25-29.

Prill-Brett., 1994. Indigenous land rights and legal pluralism among Philippine Highlanders. Law and Society Review, 28: 687-697.

Ribot, J.C., 2003. Democratic decentralization of natural resources: institutional choice and discretionary power transfer in sub-Saharan Africa. Public Administration and Development, 23 : 53-65.

Romeo, L.G., 2003. The role of external assistance in supporting decentralization reform. Public Administration and Development, 23: 89-96.

Schmeidl, S., 1998. Comparative trends in forced displacement. In: Hampton, J. (Ed.), Internally Displaced People: A Global Survey. Earthscan Publications, London.

Scudder, T., 1962. The Ecology of the Gwembe Tonga. Manchester University Press. Manchester, UK.

Scudder, T., Colson, E., 2002. Long-term Field Research in Gwembe Valley, Zambia. In: Van Kemper, R., Royce, A. (Ed.), Longitudinal Research in Anthropology. Alta Mira Press, Walnut Creek, CA.

Scudder, T., Habarad, J., 1991. Local Responses to Involuntary Relocation and Development in the Zambian Portion of the Middle Zambezi Valley. In: Mollett, J. A. (Ed.), Migrants in Agricultural Development. Macmillan, London.

Stone, G.D., 1997. Predatory sedentism: intimidation and intensification in the Nigerian savanna. Human Ecology, 25: 223-242.

Southgate, D., 1990. The causes of land degradation along "spontaneously" expanding agricultural frontiers in the Third World. Land Economics, 66: 93-101.

Thesihuesen, W., 1991. Implications of the rural land tenure system for the environmental debate: three scenarios. Journal of Developing Areas, 26: 1-24.

Townsend, N., 1997. Men, migration, and households in Botswana: an exploration of connections over time and space. Journal of Southern African Studies, 23: 405-420. 
Unruh, J.D., 2002a, Land dispute resolution in Mozambique: evidence and institutions of agroforestry technology adoption. In: Meinzen-Dick, R., Mcculloch, A., Place, F., Swallow, B. (Eds.) Innovation in Natural Resource Management: The Role of Property Rights and Collective Action in Developing Countries, Johns Hopkins University Press, London.

Unruh, J.D., 2002b, Local land tenure in the peace process. Peace Review, 14: 337-342.

Unruh, J.D., 2003. Land tenure and legal pluralism in the peace process. Peace and Change, 28: 352-376.

Unruh, J.D., 1993. Refugee resettlement on the Horn of Africa: the integration of host and refugee land use patterns. Land Use Policy, 10: 49-66.

Unruh, J.D., 1995a. Agroforestry, reforestry and the carbon problem: the role of land and tree tenure. Interdisciplinary Science Reviews, 20: 215-228.

Unruh, J.D., 1995b. The relationship between indigenous pastoralist resource tenure and state tenure in Somalia. GeoJournal, 36: 19-26.

Unruh J.D. 1996. Resource Sharing: small holders and pastoralists in Shalambood, Lower Shabelle Region. In: Besteman, C., Cassanelli L. (Eds.), The Struggle for Land in Southern Somalia: The War Behind the War. Westview Press, Boulder, CO.

Unruh J.D., 1997a. Post conflict recovery of African agriculture: critical resource tenure in Mozambique. Ph.D. Dissertation, University of Arizona, Tucson.

Unruh, J.D., 1998. Land tenure and identity change in postwar Mozambique. GeoJournal, 46: 89-99.

Unruh, J.D., 2001. Postwar land dispute resolution: land tenure and the peace process in Mozambique. International Journal of World Peace, 18: 3-30.

Uitamo, E., 1999. Modeling deforestation caused by the expansion of subsistence farming in the Philippines. Journal of Forest Economics, 5: 99-122.

Van Kemper, R., Royce, A., (Eds.). 2002. Chronicling Cultures: Long-Term Field Research in Anthropology. Alta Mira Press, Walnut Creek, CA.

Vel , J. 1992. Umbu hapi versus umbu vincent: legal pluralism as an arsenal in village combats. In: von Benda-Beckmann, F., Mvan, der, V. (Eds.), Law As A Resource in Agrarian Struggles, Wageningse Sociologisch Studies 33. Agricultural University, Wageningen, The Netherlands.

Walker, R., Moran, E., Anselin, L., 2000. Deforestation and cattle ranching in the Brazilian Amazon: external capital and household processes. World Development, 28: 683-700. 